University of Wollongong

Research Online

Faculty of Engineering and Information

Faculty of Engineering and Information

Sciences - Papers: Part B

Sciences

2017

Impact of inorganic salts on degradation of bisphenol A and diclofenac by crude extracellular enzyme from Pleurotus ostreatus

\author{
Alexander Chapple \\ University of Wollongong \\ Luong Nguyen \\ University of Wollongong, luong@uow.edu.au \\ Faisal I. Hai \\ University of Wollongong, faisal@uow.edu.au \\ Anthony Dosseto \\ University of Wollongong, tonyd@uow.edu.au
}

Md. Harun-Or Rashid

University of Wollongong, mhor972@uowmail.edu.au

See next page for additional authors

Follow this and additional works at: https://ro.uow.edu.au/eispapers1

Part of the Engineering Commons, and the Science and Technology Studies Commons

Research Online is the open access institutional repository for the University of Wollongong. For further information contact the UOW Library: research-pubs@uow.edu.au 


\title{
Impact of inorganic salts on degradation of bisphenol A and diclofenac by crude extracellular enzyme from Pleurotus ostreatus
}

\begin{abstract}
This study investigated the influence of inorganic salts on enzymatic activity and the removal of trace organic contaminants (TrOCs) by crude laccase from the white-rot fungus Pleurotus ostreatus. A systematic analysis of 15 cations and anions from common inorganic salts was presented. Laccase activity was not inhibited by monovalent cations (i.e. $\mathrm{Na}^{+}, \mathrm{NH}_{4}{ }^{+}, \mathrm{K}^{+}$), while the presence of divalent and trivalent cations showed variable impact - from negligible to complete inhibition - of both laccase activity and its TrOC removal performance. Of interest was the observation of discrepancy between residual laccase activity and TrOC removal in the presence of some ions. $\mathrm{Mg}^{2+}$ had negligible impact on residual laccase activity but significant impact on $\mathrm{TrOC}$ removal. Conversely, $\mathrm{F}^{-}$showed greater impact on residual laccase activity than on TrOC removal. This observation indicated different impacts of the interfering ions on the interaction between laccase and TrOCs as compared to that between laccase and the reagent used to measure its activity, implicating that residual laccase activity may not always be an accurate indicator of TrOC removal. The degree of impact of halides was in the order of $\mathrm{F}^{-}>\mathrm{I}^{-}>\mathrm{Br}^{-}>\mathrm{Cl}^{-}$. Particularly, the tolerance of the tested laccase to $\mathrm{Cl}$ - has important implications for a range of industrial applications.
\end{abstract}

\section{Disciplines}

Engineering | Science and Technology Studies

\section{Publication Details}

Chapple, A., Nguyen, L. N., Hai, F. I., Dosseto, A., Rashid, M., Oh, S., Price, W. E. \& Nghiem, L. D. (2019). Impact of inorganic salts on degradation of bisphenol $A$ and diclofenac by crude extracellular enzyme from Pleurotus ostreatus. Biocatalysis and Biotransformation, 37 (1), 10-17.

\section{Authors}

Alexander Chapple, Luong Nguyen, Faisal I. Hai, Anthony Dosseto, Md. Harun-Or Rashid, Seungdae Oh, William E. Price, and Long D. Nghiem 

extracellular enzyme from Pleurotus ostreatus

3

\section{Revised Manuscript Submitted to}

\section{Biocatalysis and Biotransformation}

\section{November 2017}

Alexander Chapple ${ }^{\mathrm{a}}$, Luong N. Nguyen ${ }^{\mathrm{b}}$, Faisal I. Hai ${ }^{\mathrm{a} *}$, Anthony Dosseto ${ }^{\mathrm{c}}$, Md. Harun-Or Rashid ${ }^{\mathrm{d}}$, Seungdae $\mathrm{Oh}^{\mathrm{b}}$, William E. Price ${ }^{\mathrm{d}}$ and Long D. Nghiem ${ }^{\mathrm{a}}$

a Strategic Water Infrastructure Laboratory, School of Civil, Mining and Environmental Engineering, University of Wollongong, Wollongong, NSW 2522, Australia.

b School of Civil and Environmental Engineering, Nanyang Technological University, 50 Nanyang Avenue, Singapore 639798, Singapore.

${ }^{\mathrm{c}}$ Wollongong Isotope Geochronology Laboratory, School of Earth and Environmental Sciences, University of Wollongong, NSW 2522, Australia.

d Strategic Water Infrastructure Laboratory, School of Chemistry, University of Wollongong, Wollongong, NSW 2522, Australia.

* Corresponding author: Faisal I. Hai (Email: faisal@uow.edu.au ; Tel.: + 6124221 3054) 
Abstract:

This study investigated the influence of inorganic dissolved constituents (i.e., cations and anions) on enzymatic activity and trace organic contaminants (TrOCs) removal by crude laccase from the white-rot fungus Pleurotus ostreatus. A systematic analysis of 15 cations and anions from common inorganic salts was presented. Laccase activity was not inhibited by monovalent cations (i.e., $\mathrm{Na}^{+}, \mathrm{NH}_{4}{ }^{+}, \mathrm{K}^{+}$), while the presence of divalent and trivalent cations showed variable impact from negligible to complete inhibition - of both laccase activity and its TrOC removal performance. Of interest was the observation of discrepancy between residual laccase activity and TrOC removal in the presence of some ions. $\mathrm{Mg}^{2+}$ had negligible impact on residual laccase activity but significant impact on TrOC removal. Conversely, $\mathrm{F}^{-}$showed greater impact on residual laccase activity than on TrOC removal. This observation indicated different interactions of the interfering ions with laccase and TrOCs as compared to laccase and the reagent used to measure its activity, meaning that residual laccase activity may not always be an accurate indicator of TrOC removal. The degree of impact of halides was in the order of $\mathrm{F}^{-}>\mathrm{I}^{-}>\mathrm{Br}^{-}>\mathrm{Cl}^{-}$. Particularly, the tolerance of the tested laccase to $\mathrm{Cl}^{-}$has important implications for a range of industrial applications.

Keywords: Laccase; trace organic contaminants (TrOCs); inorganic salts; halides; metals 


\section{Introduction}

Trace organic contaminants (TrOCs) include, among others, pharmaceuticals and industrial chemicals. (Hoeger et al. 2005; Lee et al. 2014; Luo et al. 2014). Conventional wastewater treatment processes are not designed to remove TrOCs and thus wastewater treatment plant effluent is considered as a major source of TrOC into the environment. TrOCs often occur in various aquatic environment at concentrations ranging from few $\mathrm{ng} / \mathrm{L}$ to $\mu \mathrm{g} / \mathrm{L}$ (Luo et al. 2014). Due to the persistence and/or bioaccumulative properties, many of the TrOCs pose risk to ecosystem and public health.

Enzymatic transformation of TrOCs has recently attracted much attention as a promising eco-friendly concept (Yang et al. 2013). Laccase (Benzenediol: oxygen oxidoreductase; EC 1.10.3.2) is of interest as it only requires molecular oxygen as a co-substrate, unlike the peroxidases which require $\mathrm{H}_{2} \mathrm{O}_{2}$. Laccase catalysed oxidation mechanism includes the reduction of molecular oxygen to water and one electron oxidation of various aromatic substrates such as TrOCs (Majeau et al. 2010; Nguyen et al. 2014b; Yang et al. 2013). Laccase has been found to be abundant in many white-rot fungi. The potential of laccase for the removal of TrOCs has been investigated intensively by various researchers. Results have demonstrated that laccase can effectively degrade a range of TrOCs (Majeau et al. 2010; Nguyen et al. 2014b; Spina et al. 2015; Tran et al. 2010; Yang et al. 2013). TrOC removal by laccase is governed by factors such as $\mathrm{pH}$, temperature, and physicochemical properties of TrOCs (Asif et al. 2017a). For example, optimum $\mathrm{pH}$ for the removal of triclosan was in the range of 5 to 5.5 (Kim \& Nicell 2006b), while diclofenac was found to be removed at the highest rate under acidic conditions ( $\mathrm{pH} 3-4.5$ ) (Nguyen et al. 2014a). TrOC properties can also strongly influence laccase performance. The compounds which contain phenolic moiety are more amendable to laccase. On the other hand, compounds which contains functional group such as carboxylic, amide, and chloride are resistant to laccase oxidation (Asif et al. 2017b; Shi et al. 2017; Tran et al. 2010; Yang et al. 2013).

Only a few studies have provided some insight into the effect of heavy metals on the removal of dye by laccase (Murugesan et al. 2009; Rodríguez Couto et al. 2005). Murugesan et al. (2009) reported that metal ions such as $\mathrm{Ca}^{2+}, \mathrm{Co}^{2+}, \mathrm{Cu}^{2+}$ and $\mathrm{Zn}^{2+}$ at a concentration of $1 \mathrm{mM}$ did not have impact on laccase performance. However, it is hypothesized that some ions may block or interfere with the active sites of laccase and thus decrease its activity (Asif et al. 2017b; Tran et al. 2010; Yang et al. 2013). Notwithstanding the available studies, the impact of 
wastewater-derived dissolved interfering compounds on the removal of TrOCs by laccase has not been fully elucidated. Dissolved organic (e.g., humic substance, organic matters) and inorganic constituents (cations and anions) widely occur in water and wastewater. Therefore, to fully uncover the potential of laccase for the removal of TrOCs, the effects of these constituent ions need to be studied.

The aim of this study was to investigate the impact that a range of dissolved inorganic ions impose on laccase including its activity level and its removal of two TrOCs, namely, bisphenol A (BPA) and diclofenac (DCF). The experiment will cover a range of common salts at different concentrations, with the objective of not only representing wastewater streams that may be encountered, but also gaining an understanding of relative ionic influences from which extrapolations can be made to predict the influence of certain wastewater components. The results will allow development of enzyme based treatment systems to be optimised, especially around TrOC removal.

\section{Materials and Methods}

\section{Materials}

\section{TrOCs and dissolved interfering salts}

Two TrOCs, namely, bisphenol A (BPA) and diclofenac (DCF) (Sigma-Aldrich, USA) were selected in this study because of their ubiquitous presence in wastewater and wastewaterimpacted waterbodies.

A set of cations and anions, which occur widely in water and wastewater, were selected to test their impact on laccase activity and its TrOC removal performance. Table 1 presents the selected cations and anions and the associated original salts.

\section{Crude laccase preparation}

A white-rot fungus Pleurotus ostreatus (ATCC 34675) was incubated in malt extract broth (2 $\mathrm{g} / \mathrm{L}$ ) at a $\mathrm{pH}$ of 4.5 to produce crude enzyme solution. The culture was kept in a rotary shaker at $28{ }^{\circ} \mathrm{C}$ and $70 \mathrm{rpm}$ for 5 days. The crude enzyme was obtained by decanting the liquid portion into a sterile container. Under these culture conditions, the enzyme preparation exhibited predominantly laccase activity (70 to $90 \mu \mathrm{M}_{(\mathrm{DMP})} / \mathrm{min}$ ) and negligible peroxidase activity. The crude laccase preparation thus obtained was stored at $4{ }^{\circ} \mathrm{C}$ until use. 
A strategic experimental plan was implemented in this study. Kim and Nicell (2006a), reported negligible impact of $\mathrm{Na}^{+}$and $\mathrm{NH}_{4}{ }^{+}$on laccase activity. Therefore, at first, $\mathrm{SO}_{4}{ }^{2-}$ dissolved from sodium and ammonium sulfate salts was tested to elucidate if $\mathrm{SO}_{4}{ }^{2-}$ has low impact so that sulfate salts can be used as a source of cations. After confirming the low impact of $\mathrm{SO}_{4}{ }^{2-}$, a range of sulfate salts (Table 1) was used.

To test the variance in influence of the anions, tests were conducted to include $\mathrm{PO}_{4}{ }^{3-}$ and $\mathrm{NO}_{3}^{-}$, and four halides i.e., $\mathrm{F}^{-}, \mathrm{I}^{-}, \mathrm{Br}^{-}$and $\mathrm{Cl}^{-}$. The anions were matched with either $\mathrm{Na}^{+}$or $\mathrm{K}^{+}$to select the salt to be added to the test solution (Table 1).

The test solution was prepared in sterile test tubes. The impact of each ion was tested at the following concentrations: $1,10,100$ and $250 \mathrm{mM}$. TrOCs were each added at a nominal concentration of $100 \mu \mathrm{g} \mathrm{L}^{-1}$ (actual measured concentrations of $116 \pm 10 \mu \mathrm{g} / \mathrm{L}$ and $109 \pm 5 \mu / \mathrm{L}$ (n $=14)$ of BPA and DCF, respectively).

A set of control tubes were prepared in the same fashion but excluding the interfering cations and anions. The test tubes were capped and incubated in a rotary shaker at $70 \mathrm{rpm}$ and 25 ${ }^{\circ} \mathrm{C}$ for $24 \mathrm{~h}$, following which the residual laccase activity and $\mathrm{TrOC}$ concentration were measured.

\section{Analytical methods}

\section{Laccase activity}

135 Laccase activity was measured by monitoring the change in absorbance at $468 \mathrm{~nm}$ due to the oxidation of 2,6-dimethoxy phenol (DMP) at room temperature over 2 min using a spectrophotometer (Spec UV-1700, Shimadzu, Kyoto, Japan) (Hai et al. 2009). Laccase activity was calculated from the molar extinction coefficient $\varepsilon=49.6 / \mathrm{mM} . \mathrm{cm}$ and expressed in $\mu \mathrm{M}$ substrate/min. Lignin and manganese peroxidase activity were determined as described elsewhere (Camarero et al. 1999).

141 TrOC analysis

142 A HPLC system (Shimadzu, Kyoto, Japan), equipped with a Supelco Drug Discovery

$143300 \times 4.6 \mathrm{~mm} \mathrm{C}-18$ column $(5 \mu \mathrm{m}$ pore size) and a UV-vis detector, was used to measure the

144 TrOC concentrations. The detection wavelength was $280 \mathrm{~nm}$ and the column temperature was

$14520^{\circ} \mathrm{C}$. The sample injection volume was $50 \mu \mathrm{L}$. The mobile phase comprised acetonitrile and 
Milli-Q water buffered with $25 \mathrm{mM} \quad \mathrm{KH}_{2} \mathrm{PO}_{4} \quad(\mathrm{pH}=4.8)$. Two eluents, A $(80 \%$ acetonitrile $+20 \%$ buffer, v/v) and B (20\% acetonitrile $+80 \%$ buffer, v/v) were delivered at

$1480.7 \mathrm{~mL} / \mathrm{min}$ through the column for $30 \mathrm{~min}$ in the following time-dependent gradient 149 proportions: [Time $(\min ), \%$ of $\mathrm{B}]=[0,80],[12,80],[20,0],[25,0],[25,80]$. Under the 150 operating conditions, the retention time of BPA and DCF was 23 and 26 min, respectively. The 151 limit of quantification for the analytes under investigation using these conditions was 152 approximately $10 \mu \mathrm{g} / \mathrm{L}$. HPLC samples were prepared by diluting the samples two-fold by 153 adding methanol to immediately stop any residual enzyme activity in the sample (Nguyen et al. 154 2014a).

\section{Results and discussion}

\section{Impact of cations}

157 Kim and Nicell (2006a) reported that sodium and ammonium ions had negligible impact on 158 laccase activity. Therefore, sodium and ammonium sulfate salts were tested first to elucidate the 159 impact of $\mathrm{SO}_{4}{ }^{2-}$. A negligible impact on laccase activity was observed until a $\mathrm{SO}_{4}{ }^{2-}$ concentration 160 of $250 \mathrm{mM}$, where a $23 \%$ drop in activity was observed. At this concentration, DCF removal 161 efficiency showed a $30 \%$ decrease compared to the control (Figure 1). Based on this initial 162 assessment of the impact of $\mathrm{SO}_{4}{ }^{2-}$, monovalent, divalent, and trivalent cations dissolved from 163 sulfate salts were evaluated for their impact on laccase activity and TrOC removal performance.

[FIGURE 1]

\section{Impact of type of cations}

Figure 2 illustrates the impact of cations on both laccase activity and its performance on TrOC removal. The results show that monovalent cations $\left(\mathrm{Na}^{+}, \mathrm{NH} 4{ }^{+}\right.$, and $\mathrm{K}^{+}$) have low impact on both laccase activity and TrOC removal. At a concentration of $250 \mathrm{mM}, \mathrm{Na}^{+}$and $\mathrm{NH}_{4}{ }^{+}$caused a $20 \%$ drop in laccase activity, whereas, $\mathrm{K}^{+}$showed positive impact with about $5 \%$ increment in observed laccase activity. Further discussion regarding this apparent increase in laccase activity is available in the penultimate section of the paper. The relative stability of laccase was reflected in the removal of BPA. On the other hand, $\mathrm{Na}^{+}$and $\mathrm{NH}_{4}{ }^{+}$showed $50 \%$ and $30 \%$ decrease in DCF removal, respectively. Comparatively less impact of cations on BPA removal can be attributed to the fact that it is a phenolic compound which is highly amenable to laccase-catalysed degradation

(Spina et al. 2015; Yang et al. 2013). 
Divalent and trivalent cations $\left(\mathrm{Mg}^{2+}, \mathrm{Ca}^{2+}, \mathrm{Cu}^{2+}, \mathrm{Zn}^{2+}, \mathrm{Mn}^{2+}\right.$ and $\left.\mathrm{Al}^{3+}\right)$ showed variable impact on laccase activity and TrOC removal. $\mathrm{Mg}^{2+}$ did not adversely affect laccase activity but showed significant impact on TrOC removal: 70 and 60\% decreases in BPA and DCF removal, respectively was observed. It is possible that $\mathrm{Mg}^{2+}$ inhibited the catalytic activity of laccase on BPA and DCF but not on DMP (the substrate used in enzyme assay). The mismatch between impact on residual laccase activity and TrOC removal suggests that residual laccase activity may not be always used to indicate the impact of interfering cations on laccase-catalysed TrOC removal.

$\mathrm{Ca}^{2+}$ and $\mathrm{Cu}^{2+}$ showed significant impact on both laccase activity and TrOC removal. Up to $93 \%$ inhibition of laccase activity was observed in the presence of $\mathrm{Cu}^{2+}$. This was accompanied by $90 \%$ and $70 \%$ drop in removal of BPA and DCF, respectively. This observation is consistent with that in the available literature. For example, $\mathrm{Cu}^{2+}$ has been shown to impose significant influence on laccase even at low concentrations (Hou et al. 2014; Lorenzo et al. 2005). Murugesan et al., (2009) reported a severe impact of $\mathrm{Cu}^{2+}$ on laccase from Ganoderma lucidum.

$\mathrm{Zn}^{2+}$ and $\mathrm{Mn}^{2+}$ demonstrated a moderate impact on both laccase activity and TrOC removal. $\mathrm{Zn}^{2+}$ caused about $30 \%$ and $40 \%$ reduction in laccase activity and TrOC removal, respectively. A stronger impact of $\mathrm{Al}^{3+}$ laccase activity and TrOC removal was noted (Figure 2). To date the mechanisms in which cations affect laccase activity and its TrOC removal performance have not been elucidated. Some possible mechanisms of metal-induced inactivation of laccase include modification of amino acid residue on enzyme, copper chelation or conformational change of the enzymes (Chmelová \& Ondrejovič 2015; Johannes \& Majcherczyk 2000).

\section{[FIGURE 2]}

\section{Impact of cation concentrations}

The cations selected in this study frequently occur in water and wastewater. Their concentration can vary with season, geographical location and type of water/wastewater. Therefore, the stability of laccase and its TrOC removal performance against several different concentrations (1-250 mM) of cations was assessed in this study (Figure 3). 
As discussed before, the monovalent cations i.e., $\mathrm{Na}^{+}, \mathrm{NH}_{4}{ }^{+}$, and $\mathrm{K}^{+}$showed little impact on laccase activity over the whole concentration range (Figure 3). A previous study by Shankar et al. (2015) also reported no impact of $\mathrm{Na}^{+}(0.5-15 \mathrm{mM})$ on laccase from Peniophora sp. On the other hand, Trovaslet et al. (2007) found that with an increase in $\mathrm{Na}^{+}$concentration from $0-$ $1 \mathrm{M}$, the activity of the laccase from T. versicolor gradually decreases from $100 \%$ to $50 \%$. Our results demonstrate that up to a concentration of $250 \mathrm{mM}$, laccase from $P$. ostreatus has strong tolerance to monovalent cations such as $\mathrm{Na}^{+}, \mathrm{NH}_{4}{ }^{+}$, and $\mathrm{K}^{+}$. Similar to laccase activity, the change in $\mathrm{Na}^{+}, \mathrm{NH}_{4}{ }^{+}$, and $\mathrm{K}^{+}$concentration did not show any considerable impact on BPA removal. However, approximately 40-50\% inhibition of DCF removal was observed at all tested concentrations of the monovalent ions $\mathrm{Na}^{+}, \mathrm{NH}_{4}{ }^{+}$, and $\mathrm{K}^{+}$, demonstrating again the resistance of DCF to laccase-catalysed degradation.

The divalent cations showed a strong effect at a concentration of $250 \mathrm{mM}$ (Figure 2). Therefore, it was interesting to observe their impacts over a lower concentration range. The residual laccase activity in the presence of $\mathrm{Mg}^{2+}$ appear to be higher than that of the control. $\mathrm{Mg}^{2+}$ was also found to increase laccase activity in a study by Shankar and Nill (2015). Further discussion regarding this apparent increase in laccase activity is available in the penultimate section of the paper.

In contrast to laccase activity, the removal of BPA and DCF gradually dropped with $\mathrm{Mg}^{2+}$ concentration-increase. $\mathrm{Ca}^{2+}$ affected laccase activity at $100 \mathrm{mM}$. However, the effect of $\mathrm{Ca}^{2+}$ on TrOC removal was significant even at $1 \mathrm{mM}$ (Figure 3). Murugesan et al. (2009) observed a concentration-dependent effect of $\mathrm{Ca}^{2+}$ on dye decolourisation by laccase from Ganoderma lucidum. Our study not only confirms such salt concentration dependent effect on TrOC but also highlights different extents of impact on laccase activity and TrOC removal.

Murugesan et al. (2009) observed a minor impact of $\mathrm{Zn}^{2+}$ on laccase and its dye decolourisation capacity. Similarly, in the current study, irrespective of its concentration, $\mathrm{Zn}^{2+}$ showed moderate inhibition of laccase activity and TrOC removal (Figure 3). $\mathrm{Mn}^{2+}$ also exhibited a moderate impact on laccase activity with around $20 \%$ inhibition at all tested concentrations. It is noteworthy that a $10 \%$ increase in BPA removal was achieved in presence of 1 and $10 \mathrm{mM} \mathrm{Mn}^{2+}$ (Figure 3). This is consistent with a few other studies who report enhanced 
enzymatic dye decolourisation in presence of metal ions in low concentration range, generally below 15 mM (Majeau et al. 2010; Murugesan et al. 2009; Shankar \& Nill 2015).

$\mathrm{Cu}^{2+}$ is of special interest as it is a key component in laccase structure. Previous studies showed no effect of $\mathrm{Cu}^{2+}$ (Murugesan et al. 2009; Shankar \& Nill 2015) up to a concentration of $15 \mathrm{mM}$. The observation of significant inhibition at $250 \mathrm{mM}$ in this study (Figure 2) necessitated testing at lower concentration range. As showed in Figure 3, $\mathrm{Cu}^{2+}$ has strong impact on both laccase stability and TrOC removal. Even at $1 \mathrm{mM}$, laccase activity was reduced by $50 \%$. TrOC removal illustrated an interesting response to $\mathrm{Cu}^{2+}$. Throughout this study, compared to BPA, DCF removal was observed to be affected more by different salts. As noted before, this can be explained by the fact that BPA has a phenolic moiety which makes it especially amenable to laccase catalysis (Majeau et al. 2010; Nguyen et al. 2014b; Tran et al. 2010; Yang et al. 2013). However, in the current study, in presence of $1 \mathrm{mM} \mathrm{Cu}^{2+}$, BPA removal was down to $10 \%$ compared to control, while DCF removal appeared less affected. It is probably because the interaction between BPA and laccase was affected in the presence of $\mathrm{Cu}^{2+}$, but not that of DCF and laccase. It is also possible that a different mode of interaction is involved here: $\mathrm{Cu}^{2+}$ is considered as a pro-oxidant and it can act as a catalytic oxidant which may form a copper-DCF complex, making DCF more amenable to degradation (Yang et al. 2013).

\section{Impact of anions}

\section{Impact of halides}

Halides are found in many industrial products and have been associated with significant environmental pollution and toxicity. Compared to $\mathrm{Cl}^{-}$and $\mathrm{F}^{-}$, the impact of halides $\mathrm{Br}^{-}$and $\mathrm{I}^{-}$on laccase have received much less attention in recent literature. Thus, the selection of all four halides in this study fills an important research gap.

In a similar approach to that taken with using sulfate salts to assess the impact of cations, the halides were matched with cations such as $\mathrm{Na}^{+}$or $\mathrm{K}^{+}$whose low impact had already been established (Figure 3). $\mathrm{Cl}^{-}$showed about $20 \%$ reduction in laccase activity at a concentration of $250 \mathrm{mM}$ (Figure 4). The extent of laccase activity reduction due to sodium chloride was even smaller than that for sodium sulfate (Figure 3). Consistent with laccase stability, $\mathrm{Cl}^{-}$effect on BPA removal was negligible. However, up to $40 \%$ removal of DCF was observed. The effect of $\mathrm{Cl}^{-}$on laccase stability and its TrOC removal performance has not been thoroughly tested in the 
literature. Champagne et al. (2013) reported that $\mathrm{Cl}^{-}$strongly affected both the laccase activity and its dye decolourisation efficiency. However, our study confirms that $\mathrm{Cl}^{-}$does not impose as high of a negative influence on laccase secreted by P. ostreatus.

In this study, $\mathrm{Br}^{-}$showed no significant impact on laccase activity. The activity dropped by $10 \%$ at $1 \mathrm{mM}$, and then levelled off at $20 \%$ for 10,100 and $250 \mathrm{mM}$. However, BPA removal efficiency gradually decreased with the increase of $\mathrm{Br}^{-}$concentration. It is noted that the $\mathrm{Br}^{-}$ion was dissolved from potassium bromide. In comparison with the impact of potassium sulfate (Figure 3), BPA removal decreased more in case of potassium bromide (Figure 4), which confirmed some impact of $\mathrm{Br}^{-}$. On the other hand, $\mathrm{I}^{-}$exhibited a strong impact on laccase activity. The residual laccase activity dropped by about $50 \%$ in the presence of $1 \mathrm{mM} \mathrm{I}^{-}$and then reduced to $16 \%$ at higher concentrations. However, only about $30 \%$ reduction in BPA removal was observed at the highest $\mathrm{I}^{-}$concentration i.e., $250 \mathrm{mM}$. This study is the first to report the impact of $\mathrm{Br}^{-}$and $\mathrm{I}^{-}$on laccase stability and its $\mathrm{TrOC}$ removal performance.

$\mathrm{F}^{-}$inhibited laccase activity significantly (Figure 4): the activity reduced by $50 \%$ and $95 \%$ at $\mathrm{F}^{-}$concentrations of $1 \mathrm{mM}$ and $10 \mathrm{mM}$, respectively. At 100 and $250 \mathrm{mM}$, no laccase activity was detected, which highlights the magnitude of the influence of $F$. From literature, a complete inhibition of enzymatic activity can be seen at $\mathrm{F}^{-}$levels as low as $1 \mathrm{mM}$ (Jung et al. 2002), but the available studies did not investigate TrOC removal. The current study additionally confirms that $\mathrm{F}^{-}$strongly affects the laccase-catalysed degradation of both BPA and DCF.

In this study, the halides were observed to have an impact on laccase activity and TrOC removal in the following order: $\mathrm{F}^{-}>\mathrm{I}^{-}>\mathrm{Br}^{-}>\mathrm{Cl}^{-}$. The difference in the extent of inhibition by halides is probably due to the different mechanisms in which each halide interact with laccase. Morozova et al. (2007) suggested that these anions bind with the Type 2 and 3 copper atoms of laccase, preventing the electron to transfer from the Type 1 site, consequently inhibiting the oxidation pathway. Farnet et al. (2008) reported that $\mathrm{Cl}^{-}$and $\mathrm{Br}^{-}$ions act as competitive inhibitors with the electron donor while $\mathrm{F}^{-}$acts as a non-competitive inhibitor.

\section{[FIGURE 4]}

Impact of $\mathrm{PO}_{4}{ }^{3-}$ and $\mathrm{NO}_{3}{ }^{-}$

$\mathrm{PO}_{4}{ }^{3-}$ and $\mathrm{NO}_{3}{ }^{-}$are commonly present in wastewater and wastewater-impacted natural waterbodies. $\mathrm{N}$ and $\mathrm{P}$-species are responsible for eutrophication and other environmental hazards. Thus, their impact on laccase activity was tested in this study. Sodium phosphate and 
sodium nitrate were used to assess the impact of $\mathrm{PO}_{4}{ }^{3-}$ and $\mathrm{NO}_{3}{ }^{-}$, respectively as the effect of $\mathrm{Na}^{+}$ was shown to be low (Figure 3). Kim and Nicell (2006a) reported insignificant impact of $\mathrm{NO}_{3}{ }^{-}$at low concentrations (around 1-2 mM) on laccase from $T$. versicolor. By investigating a broader range of concentration, our study confirms that the impact of both $\mathrm{NO}_{3}{ }^{-}$and $\mathrm{PO}_{4}{ }^{3-}$ on laccase activity can be significant at higher concentrations (Figure 5).

\section{[FIGURE 5]}

\section{Laccase activity vs TrOC removal performance}

There are several key observations made from this study that may be critical in implementing laccase treatment for TrOC removal. The first observation is the discrepancy between the impacts of the salts on laccase activity and the specific TrOC removal in some cases. This observation can be highlighted with the comparison of two sets of results, those of $\mathrm{Mg}^{2+}$ and $\mathrm{F}^{-}$. $\mathrm{Mg}^{2+}$ exhibited stable residual enzymatic activity over the 1-250 $\mathrm{mM}$ range, but suffered from a 70 and $60 \%$ drop in removal efficiency for BPA and DCF, respectively (Figure 3). In this case the laccase remains active, but the mechanism used to oxidise the target contaminant is compromised. This is contrasted with the behaviour of $\mathrm{F}^{-}$, which showed negligible residual enzyme activity at $250 \mathrm{mM}$, but still managed to achieve 35 and $11 \%$ removal of BPA and DCF, respectively. This emphasizes the different ways in which each of the ions interact and potentially affect laccase activity.

\section{[FIGURE 6]}

The second observation is the elevated residual laccase activity in the presence of some ions (Figure 6). Increased activity in whole-cell preparation in presence of some metals is well established, but there have only been a few mentions of increasing the activity of the isolated laccase by the addition of metal salts. For example, Shankar \& Nill. (2015) reported an enhancement of residual laccase activity in the presence of $\mathrm{Ca}^{2+}, \mathrm{Co}^{2+}$ and $\mathrm{Mg}^{2+}$. When testing $\mathrm{CuSO}_{4}$ and $\mathrm{MnSO}_{4}$, Farnet et al. (2008) observed an apparent increase in enzyme activity for $\mathrm{Cu}^{2+}(1 \mathrm{mM})$ and $\mathrm{Mn}^{2+}(20 \mathrm{mM})$. It is possible that the salts could increase the solubility of the substrate used for laccase activity measurement (Farnet et al. 2008), therefore increasing its exposure to laccase, allowing greater oxidation.

\section{Conclusion}


The inorganic salts evaluated in this study help isolating the relative impact of a range of ions on laccase from Pleurotus ostreatus. A variable impact on laccase and its TrOC removal performance was observed. Monovalent cations such as $\mathrm{Na}^{+}, \mathrm{NH}_{4}{ }^{+}$and $\mathrm{K}^{+}$had no or low impact on laccase activity and TrOC removal at all the tested concentrations, indicating strong tolerance of this laccase. On the other hand, divalent and trivalent cations showed different degree of influence. Specific halides also had different impacts on laccase performance: the degree of impact was in the order of $\mathrm{F}^{-}>\mathrm{I}^{-}>\mathrm{Br}^{-}>\mathrm{Cl}^{-}$. In particular, the tolerance of the tested laccase to $\mathrm{Cl}^{-}$has important implications for a range of industrial applications.

\section{Disclosure of conflict of interest}

The authors report no conflicts of interest.

\section{Funding}

This study was partially funded by the GeoQuEST Research Centre, UOW, Australia. A part of this study was conducted during Dr Nguyen's career launch fellowship at UOW. Dr Nguyen also acknowledges a postdoctoral fellowship at the Nanyang Technological University, Singapore.

\section{References}

Asif, M.B., Hai, F.I., Hou, J., Price, W.E., Nghiem, L.D. 2017a. Impact of wastewater derived dissolved interfering compounds on growth, enzymatic activity and trace organic contaminant removal of white rot fungi - A critical review. J. Environ. Manage.

Asif, M.B., Hai, F.I., Singh, L., Price, W.E., Nghiem, L.D. 2017b. Degradation of Pharmaceuticals and Personal Care Products by White-Rot Fungi-a Critical Review. Current Pollut Reports. 3, 88-103.

Camarero, S., Sarkar, S., Ruiz-Dueñas, F.J., Martínez, M.J., Martínez, A.T. 1999. Description of a versatile peroxidase involved in the natural degradation of lignin that has both manganese peroxidase and lignin peroxidase substrate interaction sites. J. Biol. Chem. 274, 10324-10330.

Champagne, P.-P., Nesheim, M., Ramsay, J. 2013. A mechanism for $\mathrm{NaCl}$ inhibition of Reactive Blue 19 decolorization and ABTS oxidation by laccase. Appl. Microbiol. Biotechnol. 97, 6263-6269.

Chmelová, D., Ondrejovič, M. 2015. Effect Of Metal Ions On Triphenylmethane Dye Decolorization By Laccase From Trametes Versicolor. nbec. 14, 191.

Farnet, A., Gil, G., Ferre, E. 2008. Effects of pollutants on laccase activities of Marasmius quercophilus, a white-rot fungus isolated from a Mediterranean schlerophyllous litter. Chemosphere. 70, 895-900.

Hai, F.I., Yamamoto, K., Nakajima, F., Fukushi, K. 2009. Factors governing performance of continuous fungal reactor during non-sterile operation - The case of a membrane bioreactor treating textile wastewater. Chemosphere. 74, 810-817. 
Hoeger, B., Köllner, B., Dietrich, D.R., Hitzfeld, B. 2005. Water-borne diclofenac affects kidney and gill integrity and selected immune parameters in brown trout (Salmo trutta f. fario). Aquat Toxicol. 75, 53-64.

Hou, J., Dong, G., Luu, B., Sengpiel, R.G., Ye, Y., Wessling, M., Chen, V. 2014. Hybrid membrane with $\mathrm{TiO}_{2}$ based bio-catalytic nanoparticle suspension system for the degradation of bisphenol-A. Bioresour. Technol. 169, 475-483.

Johannes, C., Majcherczyk, A. 2000. Natural mediators in the oxidation of polycyclic aromatic hydrocarbons by laccase mediator systems. Appl. Environ. Microbiol. 66, 524-528.

Jung, H., Xu, F., Li, K. 2002. Purification and characterization of laccase from wood-degrading fungus Trichophyton rubrum LKY-7. Enzyme Microb. Technol. 30, 161-168.

Kim, Y.-J., Nicell, J.A. 2006a. Impact of reaction conditions on the laccase-catalyzed conversion of bisphenol A. Bioresour. Technol. 97, 1431-1442.

Kim, Y.-J., Nicell, J.A. 2006b. Laccase-catalysed oxidation of aqueous triclosan. J. Chem. Technol. Biotechnol. 81, 1344-1352.

Lee, B.-E., Park, H., Hong, Y.-C., Ha, M., Kim, Y., Chang, N., Kim, B.-N., Kim, Y.J., Yu, S.-D., Ha, E.-H. 2014. Prenatal bisphenol A and birth outcomes: MOCEH (Mothers and Children's Environmental Health) study. Int. J. Hyg. Envir. Heal. 217, 328-334.

Lorenzo, M., Moldes, D., Rodríguez Couto, S., Sanromán, M. 2005. Inhibition of laccase activity from Trametes versicolor by heavy metals and organic compounds. Chemosphere. 60 , 1124-1128.

Luo, Y., Guo, W., Ngo, H.H., Nghiem, L.D., Hai, F.I., Zhang, J., Liang, S., Wang, X.C. 2014. A review on the occurrence of micropollutants in the aquatic environment and their fate and removal during wastewater treatment. Sci. Total Environ. 473-474, 619-641.

Majeau, J.-A., Brar, S.K., Tyagi, R.D. 2010. Laccases for removal of recalcitrant and emerging pollutants. Bioresour. Technol. 101, 2331-2350.

Morozova, O., Shumakovich, G., Gorbacheva, M., Shleev, S., Yaropolov, A. 2007. "Blue" laccases. Biochemistry (Moscow). 72, 1136-1150.

Murugesan, K., Kim, Y.-M., Jeon, J.-R., Chang, Y.-S. 2009. Effect of metal ions on reactive dye decolorization by laccase from Ganoderma lucidum. J. Hazard. Mater. 168, 523-529.

Nguyen, L.N., Hai, F.I., Price, W.E., Leusch, F.D.L., Roddick, F., McAdam, E.J., Magram, S.F., Nghiem, L.D. 2014a. Continuous biotransformation of bisphenol A and diclofenac by laccase in an enzymatic membrane reactor. Int. Biodeterior. Biodegrad. 95, Part A, 2532.

Nguyen, L.N., Hai, F.I., Yang, S., Kang, J., Leusch, F.D., Roddick, F., Price, W.E., Nghiem, L.D. 2014b. Removal of pharmaceuticals, steroid hormones, phytoestrogens, UV-filters, industrial chemicals and pesticides by Trametes versicolor: Role of biosorption and biodegradation. Int. Biodeterior. Biodegrad. 88, 169-175.

Rodríguez Couto, S., Sanromán, M., Gübitz, G. 2005. Influence of redox mediators and metal ions on synthetic acid dye decolourization by crude laccase from Trametes hirsuta. Chemosphere. 58, 417-422.

Shankar, S., Nill, S. 2015. Effect of metal ions and redox mediators on decolorization of synthetic dyes by crude laccase from a novel white rot fungus Peniophora $\mathrm{sp}$. (NFCCI2131). Appl. Biochem. Biotechnol. 175, 635-647.

Shi, Y., Kong, D., Liu, J., Lu, J., Yin, X., Zhou, Q. 2017. Transformation of triclosan by a novel cold-adapted laccase from Botrytis sp. FQ. Frontiers of Environmental Science \& Engineering. 11, 6. 
Spina, F., Cordero, C., Schilirò, T., Sgorbini, B., Pignata, C., Gilli, G., Bicchi, C., Varese, G.C. 2015. Removal of micropollutants by fungal laccases in model solution and municipal wastewater: evaluation of estrogenic activity and ecotoxicity. Journal of Cleaner Production. 100, 185-194.

Tran, N.H., Urase, T., Kusakabe, O. 2010. Biodegradation characteristics of pharmaceutical substances by whole fungal culture Trametes versicolor and its laccase. J. Water. Enviro. Technol. 8, 125-140.

Trovaslet, M., Enaud, E., Guiavarc'h, Y., Corbisier, A.-M., Vanhulle, S. 2007. Potential of a Pycnoporus sanguineus laccase in bioremediation of wastewater and kinetic activation in the presence of an anthraquinonic acid dye. Enzyme Microb. Technol. . . 41, 368-376. Yang, S., Hai, F.I., Nghiem, L.D., Price, W.E., Roddick, F., Moreira, M.T., Magram, S.F. 2013. Understanding the factors controlling the removal of trace organic contaminants by white-rot fungi and their lignin modifying enzymes: a critical review. Bioresour. Technol. 141, 97-108. 


\section{List of Figures}

Figure 1: Impact of sulfate $\left(\mathrm{SO}_{4}{ }^{2-}\right)$ on laccase stability and removal of BPA and DCF. Error bars present the standard deviation of duplicate samples. The dotted line indicates the initial laccase activity.

Figure 2: Effect of different cations on laccase activity and BPA and DCF removal. The cations were dissolved from sulfate salts at a concentration of $250 \mathrm{mM}$. Error bars present the standard deviation of duplicate samples. The results are normalised against the respective values in the control experiment conducted in absence of salt.

Figure 3: Effect of cation concentrations on laccase activity and BPA and DCF removal. The cations were dissolved from sulfate salts. Error bars present the standard deviation of duplicate samples. The results are normalised against the respective values in the control experiment conducted in absence of salt.

Figure 4: Effect of halides on laccase activity and BPA and DCF removal. The anions were obtained from sodium and potassium salts. Error bars present the standard deviation of duplicate samples. The results are normalised against the respective values in the control experiment conducted in absence of salt.

Figure 5: Effect of $\mathrm{PO}_{4}{ }^{3-}$ and $\mathrm{NO}_{3}{ }^{-}$on laccase activity. The anions were dissolved from sodium salts. Error bars present the standard deviation of duplicate samples. The results are normalised against the respective values in the control experiment conducted in absence of salt.

Figure 6: Relative residual laccase activity in presence of selected cations and anions showing an increase in laccase activity after incubation period. The results are normalised against the respective values in the control experiment conducted in absence of salt. 


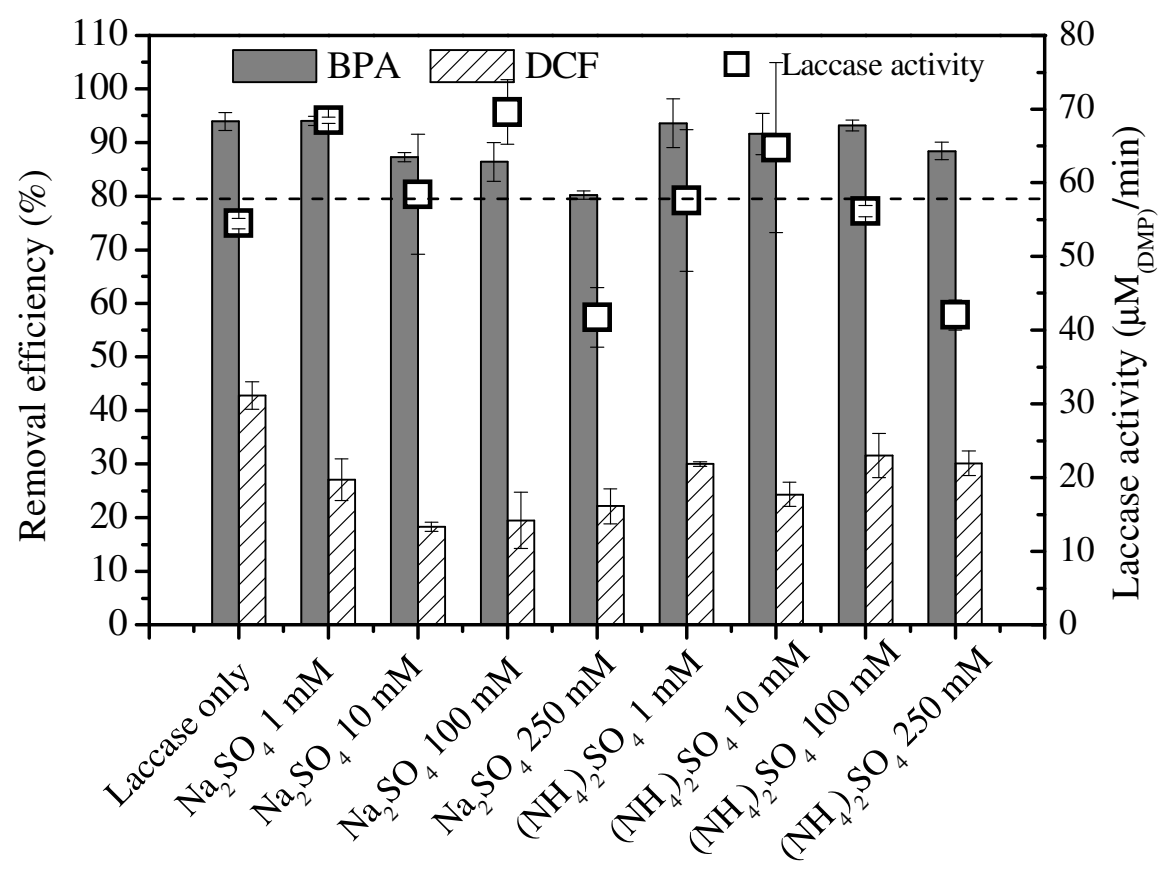

Figure 1: Impact of sulfate $\left(\mathrm{SO}_{4}{ }^{2-}\right)$ on laccase stability and removal of BPA and DCF. Error bars present the standard deviation of duplicate samples. The dotted line indicates the initial laccase activity. 


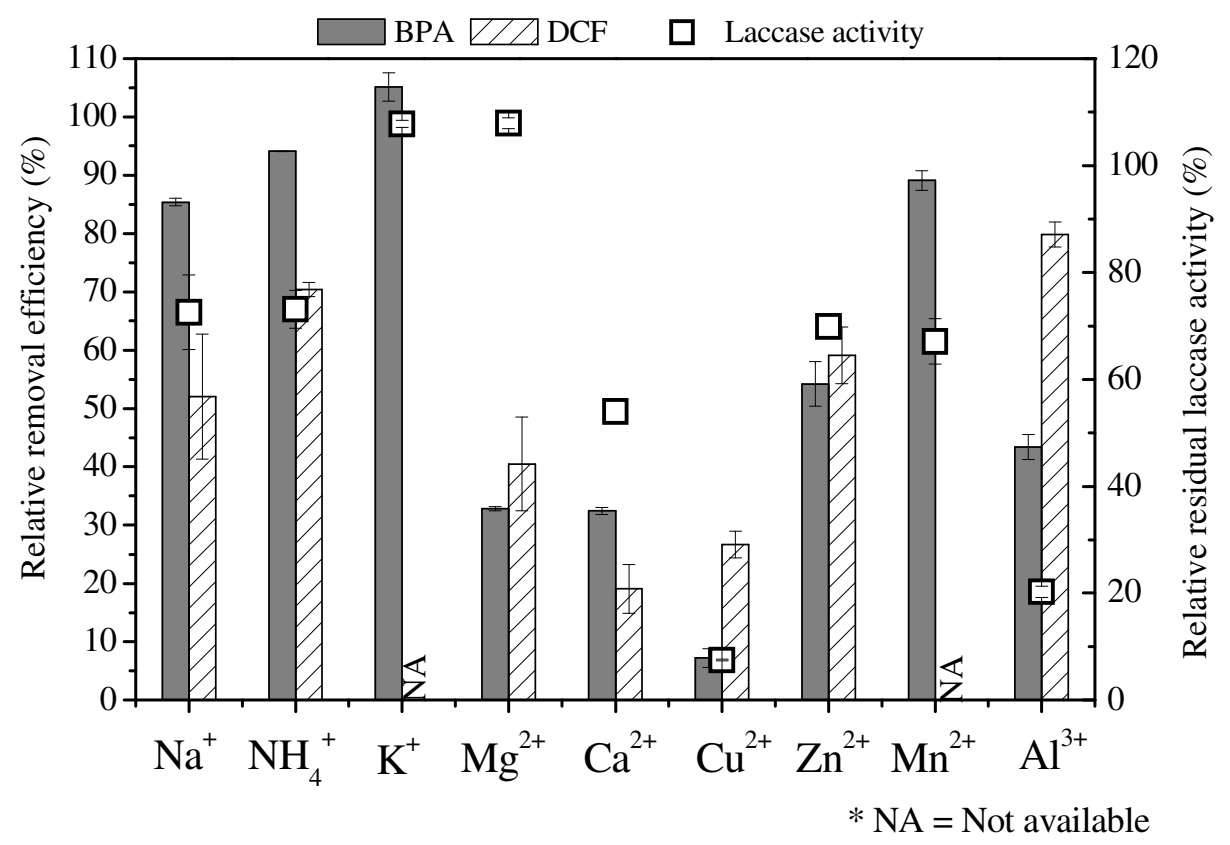

Figure 2: Effect of different cations on laccase activity and BPA and DCF removal. The cations were dissolved from sulfate salts at a concentration of $250 \mathrm{mM}$. Error bars present the standard deviation of duplicate samples. The results are normalised against the respective values in the control experiment conducted in absence of salt. 


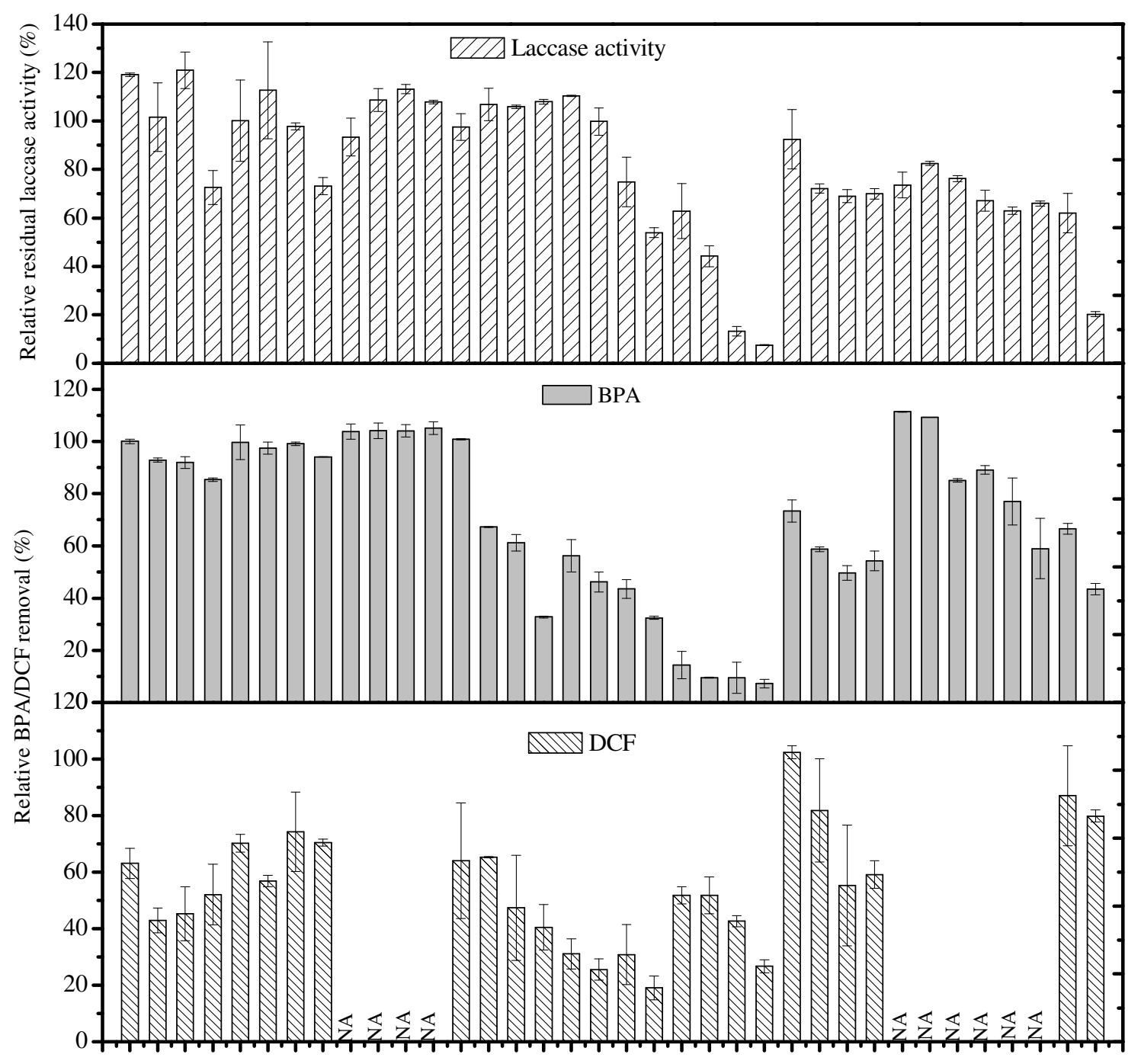

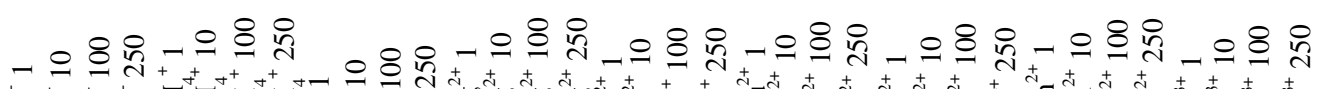

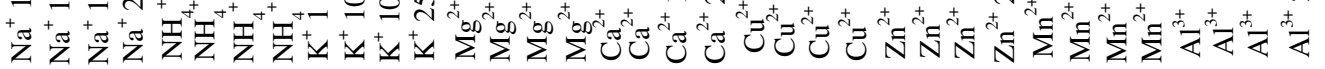
Cations

Figure 3: Effect of cation concentrations on laccase activity and BPA and DCF removal. The cations were dissolved from sulfate salts. Error bars present the standard deviation of duplicate samples. The results are normalised against the respective values in the control experiment conducted in absence of salt. 


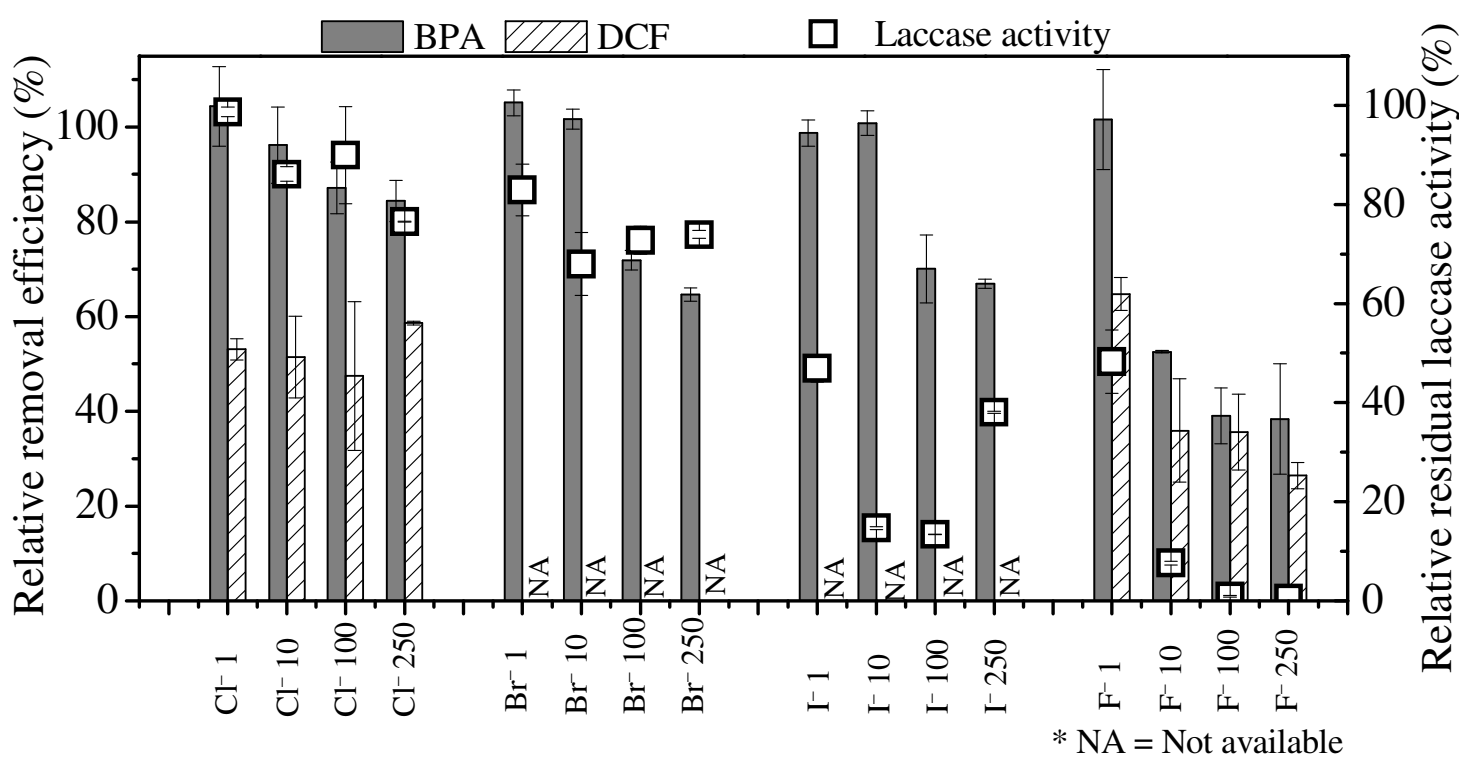

Figure 4: Effect of halides on laccase activity and BPA and DCF removal. The anions were obtained from sodium and potassium salts. Error bars present the standard deviation of duplicate samples. The results are normalised against the respective values in the control experiment conducted in absence of salt. 


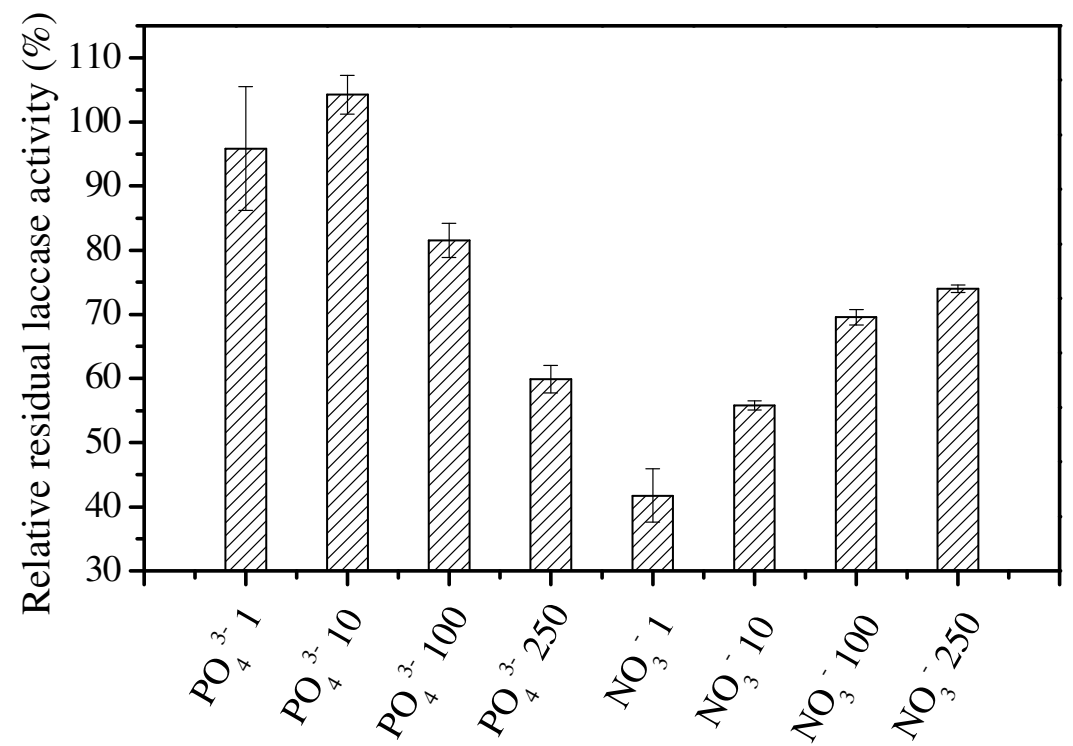

Figure 5: Effect of $\mathrm{PO}_{4}{ }^{3-}$ and $\mathrm{NO}_{3}{ }^{-}$on laccase activity. The anions were dissolved from sodium salts. Error bars present the standard deviation of duplicate samples. The results are normalised against the respective values in the control experiment conducted in absence of salt. 


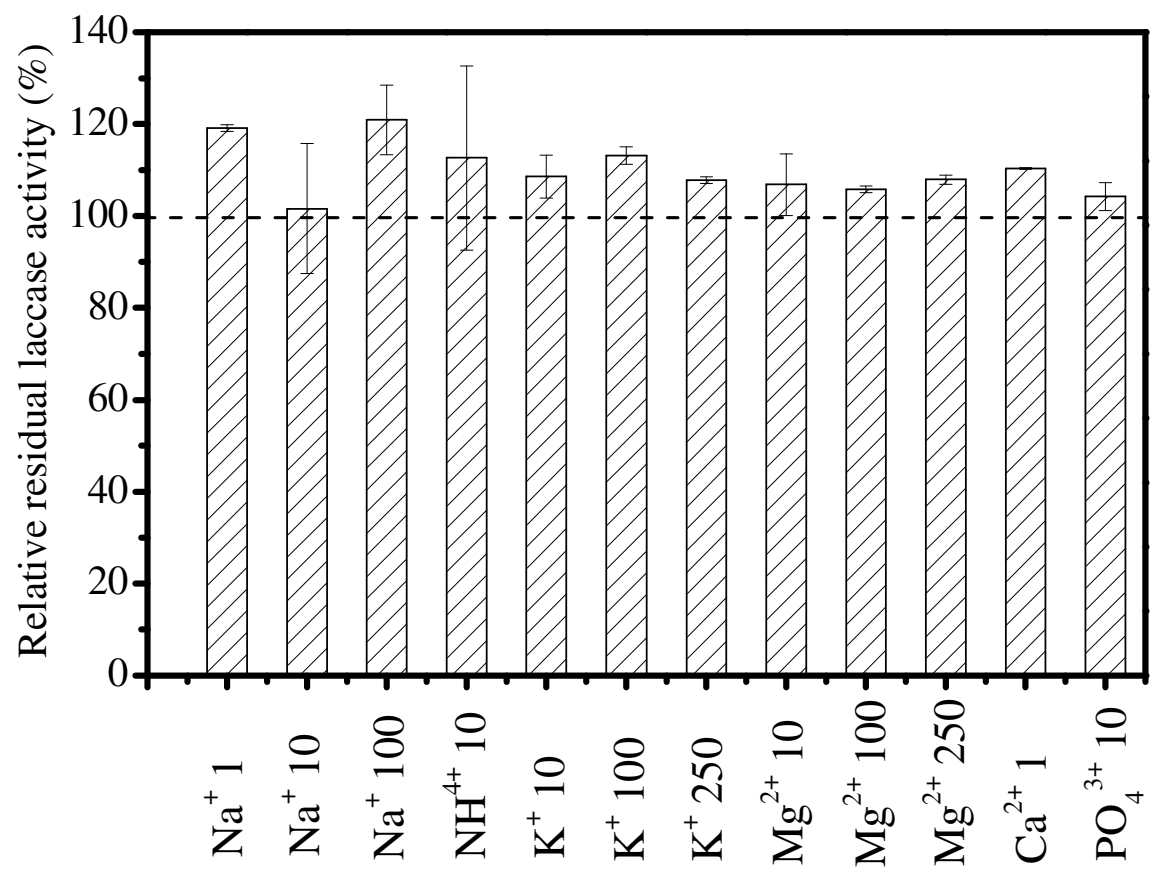

Figure 6: Relative residual laccase activity in presence of selected cations and anions showing an increase in laccase activity after incubation period. The results are normalised against the respective values in the control experiment conducted in absence of salt. 


\section{List of Tables}

Table 1: Selected cations and anions

\begin{tabular}{|c|c|c|c|}
\hline Cations & Original salts & Anions & Original salts \\
\hline $\mathrm{Na}^{+}$ & $\mathrm{Na}_{2} \mathrm{SO}_{4}$ & $\mathrm{NO}_{3}^{-}$ & $\mathrm{NaNO}_{3}$ \\
\hline $\mathrm{Mg}^{2+}$ & $\mathrm{MgSO}_{4}$ & $\mathrm{PO}_{4}^{3-}$ & $\mathrm{Na}_{2} \mathrm{PO}_{4}$ \\
\hline $\mathrm{NH}^{4+}$ & $\left(\mathrm{NH}_{4}\right)_{2} \mathrm{SO}_{4}$ & $\mathrm{Cl}^{-}$ & $\mathrm{NaCl}$ \\
\hline $\mathrm{Ca}^{2+}$ & $\mathrm{CaSO}_{4} \cdot 2 \mathrm{H}_{2} \mathrm{O}$ & $\mathrm{F}^{-}$ & $\mathrm{NaF}$ \\
\hline $\mathrm{Cu}^{2+}$ & $\mathrm{CuSO}_{4} .5 \mathrm{H}_{2} \mathrm{O}$ & $\mathrm{I}^{-}$ & $\mathrm{KI}$ \\
\hline $\mathrm{Zn}^{2+}$ & $\mathrm{ZnSO}_{4} .7 \mathrm{H}_{2} \mathrm{O}$ & $\mathrm{Br}^{-}$ & $\mathrm{KBr}$ \\
\hline $\mathrm{Mn}^{2+}$ & $\mathrm{MnSO}_{4} \cdot 4 \mathrm{H}_{2} \mathrm{O}$ & & \\
\hline $\mathrm{K}^{+}$ & $\mathrm{K}_{2} \mathrm{SO}_{4}$ & & \\
\hline $\mathrm{Al}^{3+}$ & $\mathrm{Al}_{2}\left(\mathrm{SO}_{4}\right)_{3} \cdot 16 \mathrm{H}_{2} \mathrm{O}$ & & \\
\hline
\end{tabular}

